\title{
Nigeria Housing Policy: Any Hope for the Poor?
}

\author{
Olawale, S.B ${ }^{1}$, Lawal, A.A ${ }^{2}$, Alabi, J. $\mathbf{O}^{3}$ \\ ${ }^{1}$ Building Technology Department, Yaba College of Technology \\ ${ }^{2}$ Architecture Department Yaba College of Technology \\ ${ }^{3}$ Estate and Valuation Department, Yaba College of Technology
}

\begin{abstract}
This paper appraises the Nigerian housing policies from1999 till date vis-à-vis the place of the low income earners in the policy in having access to affordable housing and decent accommodation as entrenched in the National Housing Policies. The study relies on existing pool of data that has been on by varying number of authors and other literature material published and unpublished. Government gazettes and other policy documents relating to the theme of the study were reviewed. The study method is largely desk top in nature. Virtually all literatures reviewed revealed that despite the laudability of these policies, the policies are structurally deficient as there exit no categorical statements that can adequately help the poor in meeting their housing needs. Where statements exist, event over the years have shown that no government at the three tiers level of government has come up with concrete programs in bringing into reality the desires of the poor to be decently accommodated. Where such policy programs exist, they are only meant for the poor on paper and as a political gimmick. In reality such programs end up more beneficial to the rich at the expense of the low income earners. The study recommends among other things, that government should remove all administrative bottle necks in the policy for ease implementation.
\end{abstract}

\section{INTRODUCTION}

Housing refers to the physical structure that man uses as shelter and the facilities/ amenities and other aspect of the social environment which links man with his remote and immediate environment. Housing is not only a building hut comprises all inbuilt amenities that make life comfortable for the inhabitants Zanuzdana (2012. It embraces all the environment qualities that make a particular dwelling unit livable. A good policy on housing development, anywhere in the world must seek to alleviate the problems of the low income as well as rural dwellers of a country. Experience in the past, revealed that these groups of people ( the low income group) have been left un-catered for in most housing programmes. The neglect in the society has been recognized as a major flaw in housing delivery policies in developing counties. Housing is firstly a basic need, a minimum quantity of which each household must consume as a matter of necessity and secondly meeting this basic need requires the ability to pay or put an effective demand for such a housing product.

The escalating housing problems is the resultant health problem have made government to see the need for intervention leading to the formulation of the Nigeria National Housing policy whose ultimate goal is to ensure that all Nigerian own or have access to decent housing accommodation at affordable cost. Although all countries regardless of the average standard of living, there is a large section of the population that cannot afford what would he regarded as an adequate standard of housing.

Nigerian government over the years at every level of governance recognizes the fact that housing problems are multi faceted, the most visibly tackled of these problems is that of quantitative deficiency of hoses in stock. Each prospective government realized that the most vulnerable group when it comes to housing deficiency is the low income group. Irrespective of the realization of this not objective, the low income group in the country is still bedeviled with myriad of housing problems notable among which include quantitative deficiency and their inaccessibility to decent housing. It is not uncommon to conclude that the poor for the reason of affordability cannot access decent accommodation. Government programmes on housing over the years are claimed by the government to be directed towards helping the poor to meet their housing needs, none of these programmes have succeeded in ameliorating housing challenges confronting the poor, from direct construction of low income housing to site and services scheme of the government, adequate housing still remains elusive for the low income group. Despite the policy objective of housing in the country targeted at helping the needy to overcome their housing challenges 24 years after the National Housing Policy of 1991, housing situation has become a situation where the needy have less

${ }^{1}$ Corresponding Author: steveolawale.sw@gmail.com 
access to decent housing while the privilege few have greater chances of accessing housing. Several millions of the teeming population is homeless while many live in indecent accommodation. It is in view of this that this study is contemplated. The study aims at appraising the extent to which Nigeria Housing Policy has ameliorate the housing challenges of the poor with the view of submitting a policy review that is capable of enhancing the accessibility of the poor to decent housing.

\subsection{Conceptual Issue}

\subsubsection{The low Income Earner}

The low-income group as defined by the Federal Republic of Nigeria (1991) as all wage earners and self employed persons whose annual income is $20 \%$ or below the maximum yearly income of the highest salary grade level in the civil service structure at any particular time in Nigeria. By this definition and in the context of this study the low income group comprises people who earn an average annual income of about $\mathrm{N} 816,000$ an equivalent of $\$ 4,857$ or less or its monthly equivalent of $=\mathrm{N}=68,000$ or $=\mathrm{N}=2,666(\$ 13)$ per day which are currently estimated to constitute over $80 \%$ of Nigerian workers.

\subsubsection{The National Housing Policy}

A policy is a conscious system of principles meant to guide decisions and secure rational objectives. A statement of intent, generally implemented as a procedure through programs. It is a guideline provided by the government which is aimed at meeting specific objectives or needs that may entails fiscal, institutional, legal and regulatory framework. Policy according to Sulyman, (2000) is a statement on paper by the government or an establishment as regards the way and manner in which identified problems could be mitigated. In the view of this, different sectors of the economy have policies that are used in tackling peculiar problems. Housing policy can therefore be seen as a tool that is used in overcoming housing problems, and consequently for the achievement of sustainable housing. Housing policy can therefore be seen as a statement of intent to achieve given housing objectives.

\subsection{Methodology}

The research is desk top based. The method involves review of published and unpublished literatures along salient themes that are relevant to the study.

\subsection{Housing Policies in Nigeria: A Review}

Housing policy in Nigeria is not totally new as such hosing policies in Nigeria could be discussed under five political historical phases; the pre-independent era (the period before 1960), the post- independence era (the period between 1960 and 1979), the second republic era (the period between 1979 and 1983), the military era (the period between 1984 and 1999), and the post military era or the third republic (1999 to date). Housing policy of the colonial era was characterised by direct provision of housing through the provision of staff quarters for expatriates and other indigenous staff of the multinational organisations and the administrative officials of the colonial government. The era witnessed the creation of Urban Councils in 1946, the establishment of Lagos Executive Board (LEBD) in 1928 through the Lagos Town Planning ordinance of 1928 the board later metamorphosed into the present day Lagos State Development Property Corporation (LSDPC). The corporation to date remains the largest supplier of public housing in Nigeria. The formation of the Nigerian Building Society in 1955, and the enactment of Regional Housing Corporation in 1959 all occurred during this era. The post independence era witnessed significant improvements in housing provision. This was largely enhanced by the First National Development Plan (1962-1968) and the Second National Development Plan 1970-1974). The establishment of the National Council on Housing in 1971 led to further improvement in housing delivery. The third National Development Plan (1975-1980) made further improvements on housing programmes, policies and supply in the country. The fusion of the Nigerian Building Society into Federal Mortgage Bank of Nigeria with the promulgation of Decree No 7 of 1977 also brought further improvements into housing delivery in Nigeria. In 1978, the government of Olusegun Obasanjo sees accessibility to land by the majority at the appropriate location as one of the major problems hindering both public and private sector housing delivery. The land tenure system before this period was characterised with multiple ownership pattern and concentrate land ownership in the hands of unscrupulous elements and land speculators. These accentuate the costs of land mostly in urban areas. This prompted the then government to promulgate the Land Use Act (LUA) of 1979, enacted in order to guarantee access to land by all Nigerians. Pre- promulgation of the LUA, multiple land tenure characterised the land structure of the country. The LUA came to stabilize and streamline the ownership and acquisition of land. Also, during the era, the 1979 constitution placed more emphasis on the importance of local building materials, labour and construction industry. Within same year, the Employees 
Housing Scheme Decree No 54 of 1979 was enacted. This decree made provision for staff housing and housing estates. The housing policy in the 1980s and 1990s placed more emphasis on building societies and mortgage provision. In all of these, the rural areas were neglected, left the qualitative issues in this part of the country unattended to whereas the housing stocks in the urban areas were improved upon (Ibimilua and Ibitoye 2015). Housing shortage in urban centres accentuated by high rate of urbanization prompted this selective attention by the government. The military era improved on the housing delivery policies met on ground. The period between 1979 and 1983 witnessed tremendous improvement in the provision of public housing. Direct construction of supposedly low cost housing was vigorously pursued, while governments at both the state and the fedral levels set specific targets of delivering large number of low cost housing units. The laudable goal and the vigour at which this was pursued were marred with harp corrupt practices and politicisation of the scheme. Houses delivered then were ended up been too expensive and indirectly inaccessible by the low income earners, while most at then were built in poor locations. The military coup of 1984 though a necessary evil truncated the housing delivery target of the civilian government. The military era that came on board (1964-1999) equally showed a pious intention of meeting the housing needs of the poor. Housing finance seems to pre-occupy the policy frame work of the successive governments under this era. This was enhanced by the promulgation of the Mortgage Institutions Decree No 53 of 1989. The decree promoted the realization of the major and specific objectives of the National Housing Policy. Complementing this is the Economic Liberalisation Policy of Babangida's administration which motivated the participation of the private organisation in housing delivery. This was preceded by the promulgation of the Urban and Regional Planning Decree 88 of 1992 as well as the National Housing Fund (NHF) Decree No 3 of 1992. The NHF was tasked with the responsibility of ensuring sustainable flow of mortgage for housing construction and delivery. The 1992 policy gives priority to housing finance with mandatory provision for contributory scheme of $4 \%$ by all Nigerian workers into the NHF to allow them access mortgage facility. The era witnessed the springing up primary mortgage institutions. Workers through their respective labour unions for the reason malpractices associated with the scheme kicked against the mandatory contribution and there was a policy adjustment that makes the contribution into the scheme voluntary. Before the millennium, the policy of 'housing for all in year 2000' was formulated to re-echo the policy goal of the National Housing Policy of 1999. The policy affordable for all by the year 2000 was piously pursued, but it was marred according to Ibimilua \& Ibitoye (2015) by administrative bottlenecks which made the stated aim of the policy unachievable in and beyond the year 2000. Nevertheless, in year 2002, the Housing and Urban Development Policy was formulated. This policy was meant majorly to correct the shortcomings of the Land Use Act as well as to allow land banking and ownership to operate in a free market economy. The post military era has been able to witness significant improvement in the Nigerian housing situation. Contrary to the general expectations the federal government policy on monetization and privatization are retarding the objectives of housing policies and progammes. Other constraints to housing development and delivery in Nigeria are poverty, high cost of building materials, inadequate financial instruments for mobilization of funds, short maturity preference of lending institution, political instability, sharp practices among government officials, the unresolved problem of land ownership despite its nationalisation in 1979, over-politicisation of housing programmes, high rate of rural-urban migration, as well as high rate of poverty.

\subsection{The National Housing Policy Of 1991}

Not until 1991, the country cannot be said to have a National Housing Policy, policies regulating housing prior this time were just the integral parts of the National Development Plans. The policy goal is to make all Nigerians have access to decent accommodation at affordable prices by the year 2000. The policy is comprises of about eight chapters of the following headings; Introduction, Goals and Objectives, Institutional framework for housing delivery, Land and settlements development policy, Housing finance, Building materials and construction costs, Low income housing, mobilising private sector participation, Monitoring and evaluation. The policy specifically devoted a whole chapter to the low income groups, this demonstrates how passionate the government is to the housing plights of the low income earners. The Policy highlighted the problems as peculiar to the low income group to include;

$>$ Lack of adequate finance as a major factor inhibiting the access to low income Nigerians.

$>$ The inability to provide reliable guarantors acceptable to the mortgage institutions.

$>$ Inability to afford necessary down payment or equity.

$>$ High rate of inflation.

$>$ High interest rate. 
$>$ Low earning power making it impossible to afford monthly repayment rates,

$>$ High rate of population growth and rapid urbanization.

$>$ Inadequate infrastructural facilities.

Limited access to serviced land and difficulties in obtaining certificate of occupancy.

The strategies recommended for alleviating the problems as stated in the policy 1991 are as follows. The Government Federal State and Local shall:

Make concerted efforts to eliminate the problems associated with finance.

$>$ Encourage private and public sector involvement in the direct construction of housing for letting and sale in the urban areas;

Encourage the establishment of co-operatives for direct construction of houses and distribution of building materials.

$>$ Ensure that a substantial proportion of the proposed National fund shall be made available to the low income group at low interest rates.

$>$ Encourage the establishment-of appropriate institutional machinery in all communities for efficient collection and disposal of solid waste.

Require urban planning authorities to prepare appropriate sanitation plans for all areas where centralized sewage is not available.

Encourage co-operative efforts at local level in the provision and maintenance of low income housing.

$>$ Encourage mortgage' institutions and building societies to grant small loans to low income groups to renovate and upgrade their houses.

$>$ Direct that the amortization period for mortgage loans be extended for a period up to thirty years for the low income group.

Dncourage state and local government to make available to prospective home owners technical services and professional advice during the construction and subsequent, improvement and maintenance of homes.

$>$ Extend the concepts of site and services and slum upgrading to all the states of the federation. Other strategies suggested in the National Housing Policy of 2006 include;

a. Sustain the concept of total funding of site and services to facilitate the access of the low-income group to serviced plots at reasonable cost.

b. Make forty percent (40\%) of the National Housing Trust Fund (NHTF) available for low income and rural housing.

c. Support and encourage the inclusion of community urban upgrading programmes.

\subsection{Findings}

Assessment of the performance of the policies against their set objectives in respect of the low income earners as enumerated above reveals the following;

a. On the accessibility of the poor to mortgage facility at a reducing interest of $6 \%$ : This has not been achieved because of a high interest rate which is still as high as $21 \%$ ( Emma \& Vida, 2013) a closer observation has revealed the inability of the low income earners to meet the mortgage requirement, as they don't have collateral facilities to secure the loan. Another factor militating against this objective is the administrative bottle-necks that characterized the process of accessing mortgage facility. Corruption and other sharp practices among mortgage institution officials were identify by Ibimilua (2015) as factor impeding the attainment of the objective of making the low income earners to have access to mortgage facility.

b. On Site and Services Scheme, the policy has equally failed in meeting its objective of providing serviced sites to the low income earners. Till date Government has not even provided any free site and where provided they are 
provided at exorbitant prices. A good example is the Samanda Scheme in Ibadan Oyo state where a plot in the scheme is sold as high as $=\mathrm{N}=700,000$.

c. Providing homes to the low income earners through Private Owners Participation has equally not yield any result in meeting the housing need of the poor. Houses made available through this scheme for obvious reason of profit maximization and accelerated recovery of investment by the private partners are generally on the high side in term of price, as such unaffordable for the low income earners

\subsection{National Housing Policies Challenges}

Challenges associated with the national housing policy of the country are enormous; some of these include implementation, inadequate empirical research and studies on the formulation and execution of the policy, inadequate funding, shortage of skilled manpower in the building industry, insufficient infrastructural amenities, as well as ineffective housing finance (Akeju, 2007; Aribigbola, 2006; Fadiye, 2005; Ogunsakin, 1992 and Sanusi, 1997). Other problems are rural-urban migration and high rate of urbanization, lack of effective planning, development of shanty towns, availability of dilapidated houses, as well as high cost of building materials. In spite of the housing policy, the problems of housing are witnessed both in urban and rural places. Housing problems in urban centres are caused majorly by rural-urban migration. The problem is also compounded by natural increment in population. Worse still, the effects of the housing policy are not felt in the rural areas. Rural houses are of generally poor condition, and they are characterized by lack of potable water, toilet and decent environmental condition. Land is the most essential of all the ingredients of housing scheme. It is a major input into housing and housing policy. In spite of this, the cost of land is very expensive in all Nigerian cities. The problem is also escalated by bottlenecks in the processing of certificate of occupancy ( $\mathrm{C}$ of $\mathrm{O}$ ) as well as approval of building plan.

Other lapse of the housing policy lies in the area of environmental management, social integration, as well as urban security and governance. Above all, the policy is faced with the challenge of ever-changing socio-economic and our political circumstance in the country. Another challenge that is facing the national housing policy is its inability to address the quantitative and qualitative housing problems. A major factor that is responsible for housing shortage in terms of quality and quantity is the ever-increasing demand that cannot be met by supply ( Agbola, 1998; Fadiye, 2005; Balchin, 1995; Sulyman, 2000; Jinadu, 2004; Jonna and Dean, 2012; Emma and Vida, 2013).The inability of the supply of housing to meet the ever-increasing demand is caused by its immobility. All of these impede the performance objective of the various National Housing Policies.

\subsection{Conclusion and Recommendations}

The paper from its review submits that though the objectives of the nation's National Housing Policies are laudable and take cognizance of the housing needs of the poor, but these objectives are far from being met. In view of this submission, the paper therefore recommend as follows:

An alternative to house ownership is rental housing. As rental housing is the dominant tenure for the low and medium income earners the issue of the price of rental space is critical lo renters. Government should as a matter of urgency reform mortgage finance system whereby granting of loans on long term basis would be encouraged as against a system of cash and carry which would empower the people and position them for affordable housing provision. Government should create an enabling environment for housing development by granting tax rebate on production of building materials and importation of building material available locally should be discouraged which would drastically reduce the cost of construction. Elimination of administrative and procedural delay in loans facilitation by the Federal Mortgage Hank of Nigeria should be given an utmost priority. The Nigeria Building Research Institute (NBRR1) should he properly funded to embark on modern researches on building materials. Government should encourage and subsidize private developers to produce various types of houses and making it affordable for rental purposes,

[1] Akpan, G. E. (2000): Sustainable Housing Investment and Policy Incentives in a Deregulated Nigerian Economy: Effective Housing in the 21st Century Nigeria, The Environmental Forum.

[2] Agbola, T. (1998). The Housing of Nigerians: A Review of Policy Development and Implementation, Research Report No14, Ibadan, Development Policy Centre.

[3] Akeju, A. A. (2007) Challenges to Providing Affordable Housing in Nigeria. Paper Presented at 2nd Emerging Urban Africa

[4] Aribigbola, A. (2006). Rational Choice Model and Housing Decisions in Akure, Ondo State Nigeria.Confluence Journal ofEnvironmental Studies 1 (1) 53-63. 
[5] Amdii, I. E. S. (1993) Analysis of Government Policies in Nigeria. Zaria, Nigeria. Amadu Bello University Press.

[6] Angel, S. (2000) Housing Policy Matter. Oxford, University Press.

[7] Baer, W. C. (1991) Filtering and Third World Housing Policy.Third World Planning Review 13 (1): 69-82.

[8] Balchin, P. N. (1995) Housing Policy: An Introduction. London, Routledge.

[9] Blunt, A. and Dowling, R. (2006) Home. London, Routledge.

[10] Branson, W.H. (1989): Macroeconomic Theory and Practice: New York: Harper and Row Publishers,

[11] Ekpenyong, D, B. (1993): Fundamentals of project Analysis: An Integrated Approach. Ibadan. Heinemann Educational Books

[12] Charles, C. Z. (2003). The Dynamics of Residential Segregation. Annual Review of Sociology, 29 (1): 169-207.

[13] Emma, M. and Vida, M. (2013). Austerity and Reform to Affordable Housing Policy. Journal of Housing and the BuiltEnvironment 28 (2): 3, 97-407.

[14] Fadamiro, J. A.; Taiwo, A. A. and Ajayi, M. O. (2004). Sustainable Housing Development and Public Sector Intervention ina Developing Country: Nigeria. In Ibitoye O. A.

[15] (Ed.) Scientific and Environmental Issues in PopulationEnvironment and Sustainable Development. Lagos, Graams.

[16] Fadiye, J. O. (2005). A Social Studies Textbook for Colleges and Universities.Ibadan, Akin- Johnson.

[17] Falade, J. O. (2007) Planned City as Foundation for Sustainable City. Being the Text of a Paper Presented at the Conferenceon Sustainable Cities Orgnaised by the New Economic Partnership on African Development (NEPAD), held atTranscop Hilton

[18] Hotel, Abuja. May 27-30, 2007.

[19] Fasakin, O. (1993) National Housing Policy for Nigeria. Ibadan, National Institute for Social and Economic Research.

[20] Federal Republic of Nigeria (1992) National Housing Policy.Lagos, Federal Ministry of Works and Housing.

[21] Federal Republic of Nigeria (199 1) National Housing Policy

[22] Federal Republic of Nigeria (2006) National Housing Policy

[23] Governance, Politics and Policies in Nigeria. Port Novo, Editions Sonoud' Afrique.

[24] Ogunleye, M. B. (2000): Low - Income Rental Housing in Nigerian; Issues and constraints Effective Housing in the 21st Century Nigeria, the Environmental Forum.

[25] Olotuah, A.O. (2000): The challenge of Housing in Nigeria; Effective Housing in the 21st Century Nigeria, the Environmental Forum.

[26] World Bank (1991): Making Adjustment Work for the Poor: A framework for Policy in Africa, Washington DC: World Bank

[27] Ibimilua, A. F. (2011). The Nigerian National Housing Policy in Perspective: A Critical Analysis. Journal of Social Development in Africa, 26 (2) 165-188.

[28] Ibimilua, A. F. and Ibimilua, F. O. (2011) Aspects and Topical Issues in Human Geography. Akure, B. J. Productions.

[29] Ibimilua, A. F. and Ibitoye, O. A (2015) Housing Policy in Nigeria: An Overview. American Journal of Contemporary Research 5(2) 53-59.

[30] Jinadu, A. M. (2004) Understanding the Basics of Housing. Minna, King James Publishers.

[31] Jonna, P. and Dean, G. (2012) Evaluating UK Housing Policies to Tackle Housing Affordability. International Journal ofHousing Market and Analysis 5 (3) 253-271.

[32] Kabir, O. K. (2004) Low-cost Technology and Mass Housing System in Nigerian Housing.

[33] Journal of Applied Sciences. 4(4): 565-567.

[34] Kehinde, F. (2010) Housing Policy and Development in Nigeria. In Omotoso, F; Agagu, A. A. and Abegunde, O. (eds)

[35] Lawal, M. I. (1997) Principles and Practice of Housing Management. Ile-Ife, ILCO Books.

[36] Mandelker, D. R. and Motgomery, R. (1973) Housing in America: Problems and Perspectives. Indianapolis, The Bobs Merril Company Inc.

[37] Mtafu, A. Z.; Siku, N. and Diana M. (2011) Understanding Pro-poor Housing Finance in Malawi. London, InternationalInstitute of Environment and Development.

[38] Obateru, I. R. (1982) The Structure of Physical Planning Administration in Nigeria. Unpublished Monograph.

[39] Oduntan, V. A. (1997) Policy Research as Input into Public Policy Development: The

[40] Nigerian Experience. Being the Textof a Lecture Delivered at the Policy Appraisal Research Workshop, Held at the Development Policy Centre, Ibadan,Nigeria on 17th February, 1997.

[41] Ogu, V. I. and Ogbuozobe, J. E. (2004) Housing Policy in Nigeria: Towards Enablement of Private Housing Development.Habitat International 25 (4) 473-492. 
American Research Journal of Humanities and Social Sciences, Volume 1, Issue 4, 2015

ISSN 2378-7031

[42] Ogunsakin, L. (1992) The Collapse of Official Housing Policy in Nigeria. Habitat International 16 (1):41-53.

[43] Omolabi, A.O. and Erinle, A. (2014) Social housing scheme: panacea to low income housing problems in Lagos, Nigeria being a conference paper presented at the 3rd biennial

[44] International conference on Environmental Issues(ICEI3) held at Yusuf Grillo Auditorium, Yaba College of Technology, Yaba Lagos, Nigeria 18-21 April,2014

[45] Onibokun, A. G. (1990) Urban Housing in Nigeria. Ibadan, NISER.

[46] Sanusi, Y, A. (1997) The 1991 National Housing Policy of Nigeria: An Analysis. Kaduna, Theo and Theo Solid Printers.

[47] Sulyman, A. O. (2000) Introduction to Housing: Basic Concepts and Applications. Nigeria, Olad Publishers.

[48] Wahab, K. A. (1993) Industrialisation and Urbanization. Being the Text of a Paper Presented at a Workshop organized byFEDAN/LEAD Nigeria, Lagos.

[49] World Health Organisation (WHO) (1961) Expert Committee on the Public Aspect of Housing. WHO Technical Report Series No 225, Geneva, WHO.

[50] Zanuzdana, A., Khan, M. and Kraemer, A. (201. Housing satisfaction related to health and importance of services in Urban slums: Evidence from Dhaka, Bangladesh. Social Indicators Research, V.12, no.1, pp163-185. 